\title{
Geleentheidsrede
}

\section{Om te lees of nie te lees nie ${ }^{1}$}

Jacques van der Elst

Dekaan: Lettere en Wysbegeerte

Potchefstroomse Universiteit vir $\mathrm{CHO}$

POTCHEFSTROOM

Dit is vir my allereers ' $n$ voorreg om $\mathbf{u}$ almal geluk te wens met die verwerwing van die graad of diploma, 'n belangrike mylpaal in u lewe. Ek hoop dat hierdie stylvolle geleentheid vir $u$ 'n mooi herinnering gaan wees.

\section{Omwenteling en geestesgoedere}

$\mathrm{U}$ het vir 'n graad gestudeer in 'n tyd waarin Suid-Afrika sy grootste omwenteling beleef het en waarin veranderings aan die orde van die dag is sommige veranderings wat te doen kan hê met die ondermyning van ons daaglikse bestaan, ons geestelike en intellektuele lewe. Dis 'n tyd waarin ook 'n aanslag geloods word op universiteite en daarmee ook op ons akademiese standaarde.

Dit wat ons jaloers wil bewaak as 'n elitistiese instelling - naamlik 'n universiteit - en wat tog deur die nasionale regering as 'n nasionale bate beskou word - staan in die branding.

Die veranderings wat wel in die RSA plaasvind, en nog gaan plaasvind, beproef baie Suid-Afrikaners se aanpassingsvermoë tot die uiterste. Ek dink byvoorbeeld aan die pas voorgestelde nuwe wetgewing oor loterye op nasionale en provinsiale vlak, en die wettiging van casino's. Ons is vir 'n wyle nog gespaar vir die wettiging van hondewedrenne. Die waan van 'n klein bietjie geestelike geborgenheid wat ons in ' $n$ vorige bedeling gehad het, is vir baie van ons vir goed verby.

In dié omstandighede moet ons onherroepelik vasklou aan ons geestelike goedere. Hier dink ek nie alleen in die besonder aan ons godsdienstige lewe nie, maar ook aan ander dinge wat met die dieper dimensie van ons bestaan te doen het - die dinge waarmee $u$ as geesteswetenskaplikes $u$ in die besonder

1 Geleentheidsrede gehou op 14 Maart 1995 by 'n gradeplegtigheid van die Potchefstroomse Universiteit vir CHO. 
Om te lees of nie te lees nie

besig gehou het. Daarmee wil ek nie sê dat natuurwetenskaplikes hulle nie besig hou met die dieper dinge van die menslike bestaan nie. Juis by ons Universiteit is dit seker so dat die natuurwetenskaplikes nie slegs met 'n koue objektiewe blik na ons wêreld kyk nie. Ek wil juis glo dat die natuurwetenskaplikes, in die PUK se tradisie die voetspore van God in die skepping raaksien. Hulle beskouing staan reg teenoor die siening dat die wêreld ná ' $n$ enorme ontploffing tot stand gekom het sonder ' $n$ ingreep van God en dat die mens uiteindelik maar net 'n versameling atome is wat deur natuurwette beheers word.

\section{Isaac Newton - 'n ingesteldheid teenoor 'n objektiewe werklikheid}

Terloops, ek het nou die dag 'n stukkie gelees wat my as literator laat dink het dat dié geskrif van 'n beroemde natuurwetenskaplike netsowel dié van 'n literator kon gewees het. In wat hy gesê het en in hoe hy dit gesê het, is vir my 'n sintese tussen die natuurwetenskappe en die geesteswetenskappe geleë.

Dié natuurwetenskaplike, Isaac Newton, het naamlik in 1672 die volgende pragtige prosa geskryf oor die skeiding van wit sonlig. Ek laat hom in vertaling aan die woord. Hy spreek sy lesers soos volg aan:

Om my belofte wat ek 'n rukkie gelede aan u gemaak het na te kom, sal ek u nou sonder verdere omhaal vertel hoe ek in die jaar 1666 (toe ek my besig gehou het met die slyp van lense met 'n nie-bolvormige uiterlike) 'n driehoekige glasprisma gemaak het om daarmee die beroemde verskynsels van kleure te ondersoek. Ek het my kamer verduister, maar'n klein gaatjie in die vensterluike gemaak om 'n toereikende hoeveelheid lig binne te laat. Ek het die prisma in die ligbaan geplaas met die bedoeling dat die lig gebuig sou word na die muur aan die ander kant. Eers was dit vir my 'n aangename gewaarwording om die helder en intense kleure te sien wat hierdeur te voorskyn gekom het. Maar na 'n oomblik, toe ek noukeuriger gekyk het, was ek verras om te sien dat die spektrum 'n langwerpige vorm gehad het, terwyl ek op grond van gangbare opvattings verwag het dat dit sirkelvormig sou wees.

Tot sover Isaac Newton. Dit klink soos 'n storie: Hier is iemand aan die woord, 'n navorser, wat 'n belofte nakom, wat lense slyp, wat prismas vervaardig en trots daarop is, en wat waardering het vir mooi kleure. Vervolgens verwag hy dat iets moet gebeur, maar dan word hy verras deurdat hy iets anders sien. Al hierdie gewaarwordinge teken hy onbevange aan.

Die styl van so 'n geskrif is seker nie meer vir hedendaagse natuurwetenskaplikes aanvaarbaar nie. Tog het Newton 'n voorbeeld gestel van 'n 
Jacques van der Elst

innerlike geestesgesteldheid ten opsigte van die objektiewe werklikheid. Dieselfde word gedoen in die geesteswetenskappe.

Met hierdie voorbeeld wil ek sê dat die natuurwetenskaplike in hierdie geval, Newton, besig is met die ontsluiering van die geheime van die wêreld en die menslike bestaan. Dieselfde word gedoen in die geesteswetenskappe. Ek het vroeër gesê dat ons en $u$ in ' $n$ veranderende Suid-Afrika moet vasklou aan ons geestelike goedere. Ek wil dan vervolgens praat oor 'n belangrike hulpmiddel by die behoud en opbou van hierdie geestelike vermoëns, ondanks die aanslae van 'n veranderende wêreld. Hierdie hulpmiddel is die geskrewe woord.

\section{Die geskrewe woord - 'n hulpmiddel om ons geestelike welsyn in stand te hou}

$U$ het oor die afgelope paar jaar - trouens ook vroeër op skool intensief gebruik gemaak van die geskrewe woord - boeke om u kennis aan te vul. Dikwels, meen ek, was boeke seker ' $n$ aanvulling op die leerstof wat $u$ deur en van 'n dosent gekry het.

Ek het dit dan in die besonder oor die waarde van die boek. As ek in die geskiedenis kan teruggaan, dan kan ek verwys na die Middeleeue en in die besonder na ene Walter, die skatbewaarder van die Onse Liewe Vroukatedraal in Doomik, wat in die jaar 1277 sy hele boekery aan die kerk bemaak het. Die kerk het die boekery dadelik verkoop vir die reusebedrag van 140 Paryse ponde en dit vir elf bande. As 'n mens hierby in ag neem dat daar in hierdie tyd in dieselfde stad ' $n$ herehuis verkoop is vir 85 ponde - dan lyk dit vir my asof die elf boeke meer werd was as twee groot huise.

Omstreeks 1400 was die gemiddelde prys van 'n boek in Parys gelyk aan die weeksalaris van ' $n$ amptenaar aan die hof van die koning. Die koste van twee gesangboeke was toe meer werd as die jaarsalaris van 'n professor.

Die belangrike digter, literator en diplomaat aan die Engelse hof, Chaucer, het aan die einde van die veertiende eeu in totaal sestig boeke gehad - iets wat in daardie tyd 'n ryk boekebesit was. Die grootste biblioteek van die Middeleeuse Christendom, die Sorbonne in Parys, het in die 14de eeu 1722 bande gehad - 'n ongeëwenaarde boekery.

Vandag is die persentasie heeltemal anders. Die getalle boeke is natuurlik baie groter. Kom ons neem 'n Wes-Europese land as voorbeeld, naamlik Nederland. Die huidige gesamentlike boekebesit van Nederlandse huisgesinne beloop meer as 11/4 miljard bande dus - eenduisend vyfhonderd miljoen boeke. Verder is daar nog negentig miljoen boeke in tweeduisend biblioteke en beskik die sentrale boekebedryf in Nederland oor meer as 86000 verskillende titels wat 
daagliks aan klante gelewer kan word - ek praat dus nou van 'n klein landjie soos Nederland met 14/15 miljoen inwoners.

Wat is die leespatroon in ons eie land? Vandat 'n groot deel van die mense oorgeskakel het van lees na kyk (dit wil sê die TV) en daar 'n mentaliteit van God save the screen ontwikkel het, is die leeskultuur ondermyn. Die televisie het die leeslamp laat verdof. In die ontstane kykkultuur word selfs ons persoonlikhede aangetas. Sekere televisieprogramme het 'n ingeblikte lag of applous vir die flouste kwinkslae of grappies. 'n Mens word min of meer gedwing om saam te lag. En as 'n mens nie sterk staan nie het jy netnounetnou 'n minderwaardigheidskompleks oor jou eie humorsin.

'n Boek daarenteen as dit sy sout werd is - en ek is natuurlik bewus daarvan dat daar boeke én boeke is - stel jou in staat om jouself te wees sonder dat jy deur 'n televisiebeeld gemanipuleer word.

As daar een ding is wat ek opreg hoop, dan is dit dat $u$ tydens $u$ drie- of vierjarige studie geleer het om krities en tegelykertyd skeppend met sekere boeke om te gaan. As u dit nie gedoen het nie, dan het iets verlore gegaan. Dan het ons as universiteit en dosente ons doelwitte met $u$ gemis.

Juis die geskrewe woord, die boek, kan 'n mens oefen om kreatief te wees. Om te lees is ook 'n kreatiewe proses. Wat een leser onttrek aan 'n gedrukte bladsy hoef nie noodwendig dieselfde te wees as wat ' $n$ ander daaruit haal nie. Die leesproses is tegelykertyd 'n stimulerende proses. Die boekleesproses verskaf eintlik ' $n$ handleiding vir ons lewe - in watter beroep 'n mens ook al gaan staan. Verstaan my mooi, ek is nie besig met 'n tirade teen ons kykkultuur nie. Wie ervaar byvoorbeeld nie soms die vreugde van 'n heerlike ontspannende Vrydagaand tuis vas aan die slaap voor die kykkassie nie! Natuurlik moet ek toegee dat televisie ' $n$ magtige medium is wat tot seën en geestesverryking kan dien. Ek dink byvoorbeeld aan die tegniek van die televisie as wonderlike hulpmiddel in onderrig, iets wat ons Universiteit daadwerklik ontgin in die ontwikkeling van byvoorbeeld afstandsonderrig.

\section{Ontwikkel 'n leeskultuur}

Om terug te kom by boeke: Boeke open nuwe wêrelde; brei ons horisonne uit. Hulle plaas ons voor die probleme van ander mense en verbreed die insig in jouself.

Boeke kan 'n mens bring by die oplossing van ons eie lewensraaisels - boeke kan lewensverdieping bring. Met boeke kan 'n mens reise onderneem.

Kortom: 'n Mens se gees word verryk deur die lees van boeke. lemand wat nie lees nie verarm homself. Mense wat lees, hoef nie eensaam te wees nie. 
Die leesgewoonte moet 'n mens aankweek. Jy moet ook 'n leessmaak ontwikkel. As jy nie by die huis ' $n$ aanvoeling vir lees met die paplepel ingekry het nie, dan kan dit wees dat lees nie deel van jou lewe word nie. As die skool en biblioteek nie ook 'n steentjie bydra nie is kinders leesverlore. As 'n jeugdige geen leesstimulering kry nie of as hy aanvanklik aan te moeilike leesstof blootgestel word, dan loop hy gevaar om hom oor te gee aan die kykvermaak. En die beeldkultuur van die televisie kan lei tot taalarmoede, denkverskraling en luisterverskraling - so iets soos georganiseerde geheueverlies. Veral kinders in die leeftydgroep 12-13 kan onherstelbare skade ly as hulle nie leesstimulasie kry nie. Kinders in dié leeftydgroep se grammatikale vaardighede stabiliseer juis dan. Dit raak byvoorbeeld sy woordeskat en algemene kommunikasievermoë. As dit onderontwikkel bly, kan dit ernstige konsekwensies hê. Kinders kan vir hulle lewe skade ly as televisie byvoorbeeld hulle hoofvorm van ontspanning is. Benewens taal- en kommunikasievaardighede word kinders se algemene sosiale ontwikkeling ook ondermyn.

Kenners het vasgestel dat die taalgebruik in 'n sepie soos Dallas ter wille van kommunikasie met die kykers op die laagste opleidingsvlakke oorvereenvoudig is. Gekompliseerde sinne is uit en enkelvoudige sinne is in.

Ek het eintlik hier lees- en kykkultuur met mekaar vergelyk. Die eersgenoemde is ' $n$ eeueoue kultuur wat die mens se lewe van die vroegste tye af verryk het en ons seker tot die wederkoms sal verryk ondanks alle bystand van die elektroniese wonderwêreld. Ek dink nie die boek en die waarde van die boek sal ooit geklop kan word deur iets anders nie.

Ek wil ' $n$ beroep op $u$ doen om die leeskultuur wat $u$ hopelik al by die huis gekry het, maar wat vir seker deel van u paar jaar op die PUK geword het, in stand te hou. Dit is ' $n$ belegging vir die lewe.

\section{Ten slotte}

Met die woord het alles begin. God het met woorde geskep. God het die vleesgeworde Woord na ons gestuur. Hy het die grootste leesboek van alle tye aan ons gegee - die Bybel.

Wanneer ons na 'n preek luister, dan luister ons na die verslag van iemand wat gelees het onder leiding van die Heilige Gees.

Ja, sekere boeke is ook dikwels skadelik vir die gees, maar hoef nie so 'n oorweldigende en onbeheerbare indringer soos byvoorbeeld die televisie te wees nie. Die handhawing van 'n leeskultuur en die handhawing van die waarde van die boek kan help om die aanslag van vervlakking in ons huidige samelewing te weerstaan. Ek pleit hartstogtelik vir die boek - ek pleit vir lees deur oud en jonk. 
